\title{
Cytopathologic Diagnosis of Spontaneous Infarction of Fibroadenoma of the Breast
}

\section{Spontan Enfark Gösteren Meme Fibroadenomunun Sitopatolojik Tanısı}

\author{
Neelam WADHWA ${ }^{1}$, Richa JOSHI ${ }^{1}$, Nidhi MANGAL ${ }^{1}$, Nirupma Panikar KHAN ${ }^{2}$, Mohit JOSHI ${ }^{1}$ \\ Department of Pathology, 'University College of Medical Sciences, University of Delhi and ${ }^{2}$ Guru Teg Bahadur Hospital, Shahdra, DELHI, INDIA
}

\begin{abstract}
Infarction is an uncommon event in a fibroadenoma, which is the commonest benign tumor of the breast. Most often it occurs in pregnancy, lactation or is secondary to fine needle aspiration. Spontaneous infarction of a fibroadenoma in the absence of a predisposing condition is very rare. The cytopathologic features of infarction are necrosis and worrisome nuclear features, which are often misinterpreted as either inflammation or malignancy. We detail a report of accurate cytopathologic diagnosis of spontaneous infarction of fibroadenoma in a 17 -year-old adolescent non pregnant girl. Careful attention to the cytopathologic clues like uniform thickness of the necrotic epithelial fragments, branching pattern reminiscent of the staghorn pattern despite atypical nuclear features and clinical details like young age of the patient and recent onset pain in a pre-existing lump helped arrive at the correct diagnosis and spared the patient of a radical excision. To the best of our knowledge, there are no earlier reports of correct cytopathologic diagnosis.
\end{abstract}

Key Words: Fibroadenoma, Breast, Infarction, Fine needle biopsy, Cytology

\begin{abstract}
ÖZ
Memenin en sık benign tümörü olan fibroadenomda infarkt nadiren görülür. En sık olarak gebelik ve laktasyon dönemlerinde ya da ince iğne aspirasyonuna bağlı olarak gelişir. Bu predispozan durumların yokluğunda, fibroadenomun spontan infarktı son derece nadirdir. Enfarktın sitopatolojik özellikleri, nekroz ve kuşkulu nükleer özelliklerdir. Bunlar inflamasyon ya da malignite olarak yanlış yorumlanabilir. $\mathrm{Bu}$ olgu sunumunda, 17 yaşındaki bir hastada gelişen spontan fibroadenom infarktının sitopatolojik özellikleri sunulmaktadır. Nekrotik epitelyal fragmanların uniform kalınlığ geyik boynuzu şeklinde dallanma patterni, atipik nükleer özellikler ve hastanın yaşı, uzun süredir var olan kitlede son dönemde başlayan ağrı gibi klinik ayrıntılar doğru tanıya ulaşmada ve hastayı radikal eksizyondan alıkoymada yardımcı oldu. Literatürde doğru sitopatolojik tanıya ulaşılan olgu bildirimine rastlanmadı.
\end{abstract}

Anahtar Sözcükler: Fibroadenom, İnfarktüs, Meme, İnce iğne biyopsisi, Sitoloji

\section{INTRODUCTION}

Infarction rarely occurs in a fibroadenoma, the most common tumor of the female breast. Most cases of infarction are secondary to fine needle aspiration (1). Spontaneous infarction is extremely uncommon, and typically seen in pregnant or lactating women (2,3). Most cases of infarction of fibroadenoma are misdiagnosed clinically, radiologically and cytopathologically as malignant masses, thus prompting a radical surgical intervention (3-6).

Spontaneous infarction of fibroadenoma of the breast in non-pregnant women is rarely described in the medical literature, and correct cytopathologic diagnosis has not been previously reported $(4,5)$. Herein, we report a case of spontaneous infarction of fibroadenoma of the breast in a non pregnant adolescent girl diagnosed on fine needle aspiration cytopathology. The cytopathologic diagnosis was confirmed by histologic evaluation of the conservatively

(Turk Patoloji Derg 2014, 30:237-240)

Received : 09.11.2011 Accepted : 07.02.2012 excised surgical specimen. We also highlight the diagnostic cytopathologic features of infarction, the recognition of which spared the patient a radical surgery.

\section{CASE REPORT}

A 17-year-old adolescent non pregnant girl presented with a lump in the upper inner quadrant of her right breast for the last 3 months which had recently become painful. There was no history of trauma, fever, hormone intake or family history of breast carcinoma. A well-circumscribed, mildly tender, mobile mass, $4 \times 4 \times 3 \mathrm{~cm}$ was palpable in the right breast. Bilateral axillae and the contra-lateral breast did not reveal any lump. Fine needle aspiration was performed percutaneously using a $10 \mathrm{~mL}$ syringe and a 23 $G$ needle under sterile conditions. May-Grünwald-Giemsa and Papanicolaou staining were done on air-dried and wetfixed smears, respectively.

Correspondence: Neelam WADHWA

University of Delhi, University College of Medical Sciences, Department of Pathology, Shahdra, DELHI, INDIA

E-mail: drneelam428@yahoo.co.in Phone: +9119873647787 
Air-dried May-Grünwald-Giemsa stained smears showed sheets and clusters of epithelial cells, some with typical branching staghorn shapes. Although the overall impression on low magnification was suggestive of a fibroadenoma; the clusters appeared ghostly and necrotic (Figure 1). The cells were discohesive and the edges of the epithelial clusters were frayed, unlike the well-defined edges usually seen in fibroadenoma. The stromal fragments were magenta but dull, lacking the usual refractile quality seen in fibroadenoma (Figure 2). Most nuclei were found to be

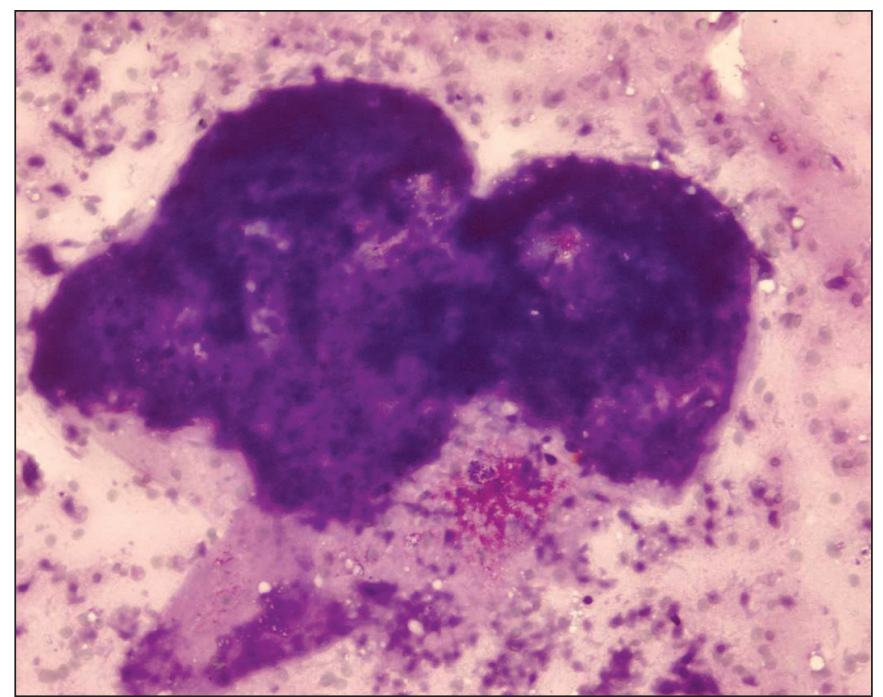

Figure 1: Necrotic epithelial fragments showing well defined contours reminiscent of fibroadenoma. Note the uniform thickness of the fragment (May Grünwald-Giemsa; x400).

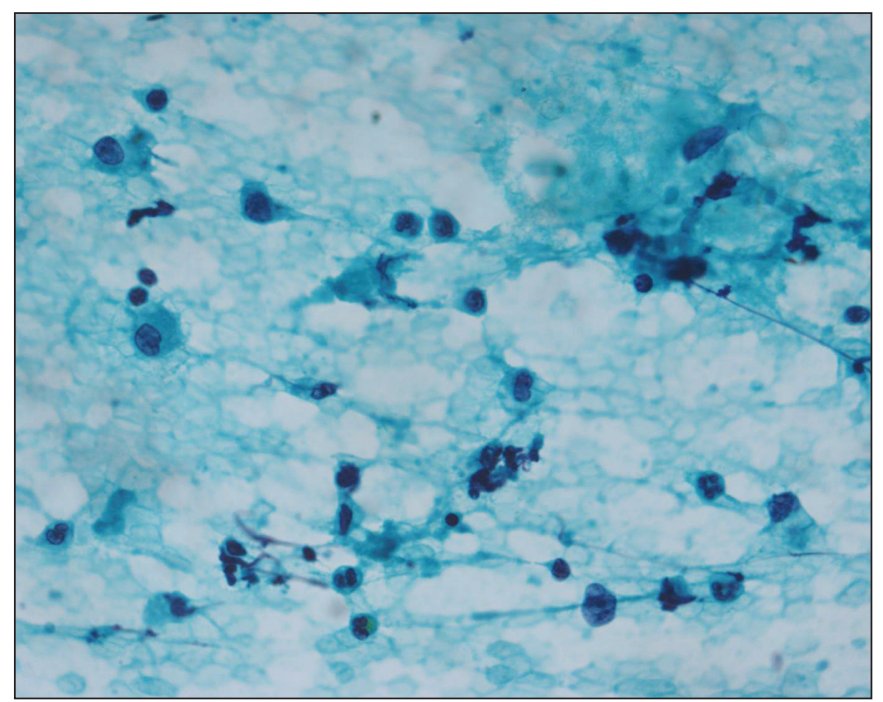

Figure 3: Individually scattered cells devoid of nuclei in the background. Only occasional cells show hyperchromatic nuclei (Papanicolaou stain; x400). missing both in the epithelial and stromal fragments. The occasional nuclei were visualized better on Papanicolaustained smears: these were enlarged, smudgy, and focally irregular (Figure 3). In isolation, these cells could have been misinterpreted as malignant cells in a necrotic background. Considering the cellular cohesion and largely preserved shape of the epithelial cell clusters and the history of recent onset pain, despite the presence of occasional worrisome nuclei, a diagnosis of spontaneous infarction of FA of the breast was rendered.

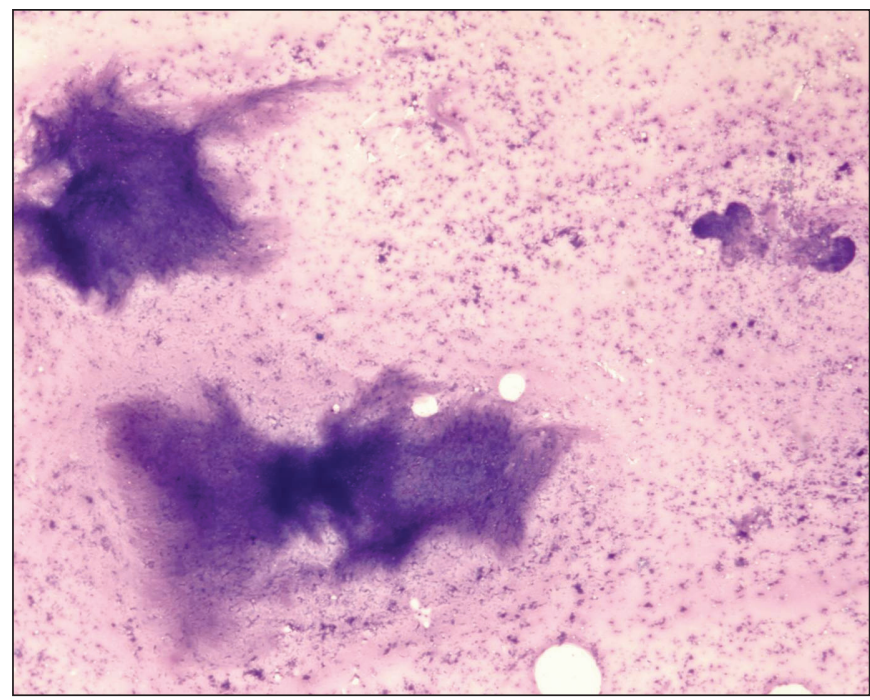

Figure 2: Dull looking necrotic stromal fragments with irregular shapes and variable thickness. Contrast these with the necrotic epithelial fragments on their right for regular outlines and uniformity of thickness (May Grünwald-Giemsa; x40).

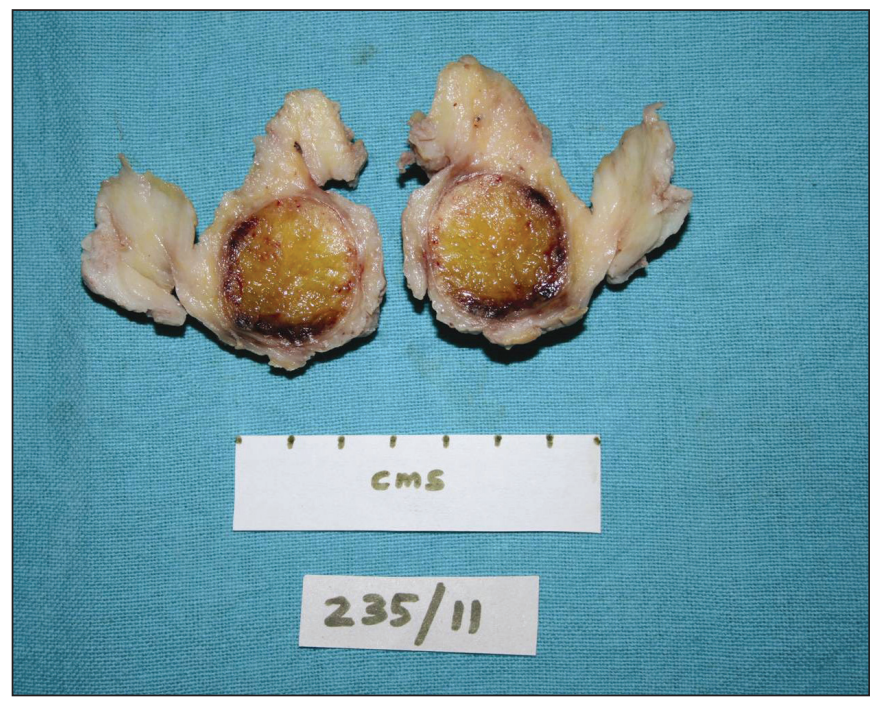

Figure 4: Well circumscribed yellow colored tumor with areas of hemorrhage is seen distinct from the surrounding breast parenchyma. 


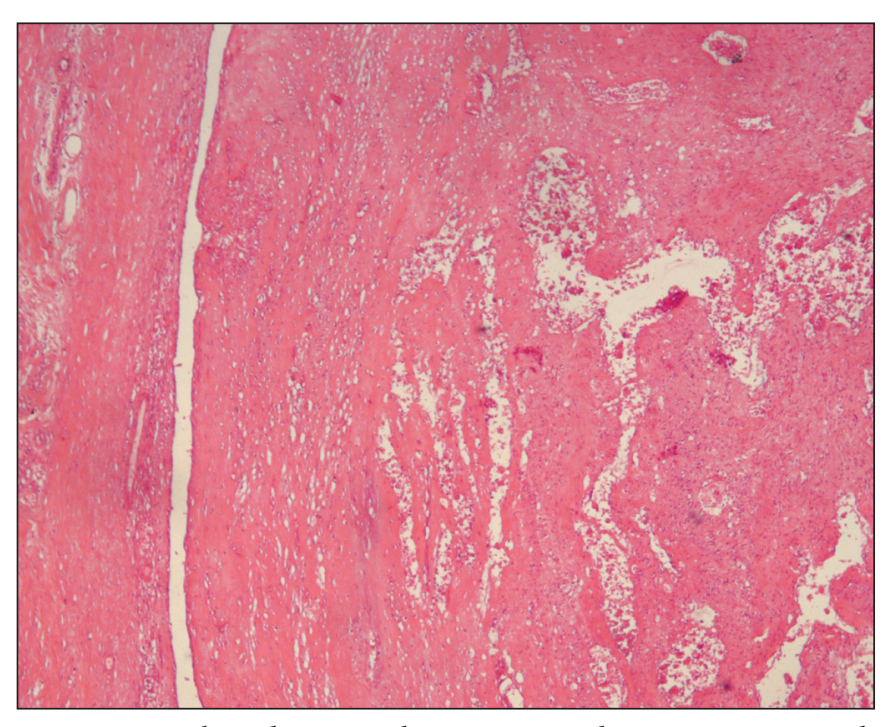

Figure 5: Fibroadenoma showing coagulative necrosis with partially preserved intra-canalicular architecture and loss of nuclei. Adjacent breast parenchyma is identifiable on the right (H\&E; $\mathrm{x} 40)$.

The breast mass was conservatively excised. The surgical specimen measured $5 \times 4.5 \times 3 \mathrm{~cm}$, and contained a wellcircumscribed $2.2 \mathrm{~cm}$ tumor. Grossly, the tumor was yellow with tiny foci of hemorrhage (Figure 4). The specimen was fixed in $10 \%$ neutral buffered formalin, paraffin embedded and $4 \mathrm{~mm}$ thick hematoxylin and eosin stained sections prepared. The sections showed coagulative necrosis with only ghostly outlines of epithelial fronds with intra-canalicular and peri-canalicular stromal proliferation (Figure 5). As in the cytopathologic smears, nuclei were conspicuously absent in both epithelial and stromal components. The tumor margin showed mild acute inflammatory infiltrates; no thrombotic or occlusive vascular lesions were identified.

\section{DISCUSSION}

Fibroadenoma accounts for up to $50 \%$ of all palpable breast lumps in young females (3). Development of infarction in a fibroadenoma of the breast is an uncommon event, seen in $0.5 \%$ to $1.5 \%$ of all cases including those seen in pregnant women $(2,3)$. A painful breast lump is the most common complaint; other presentations include lump with irregular margins, fixity to underlying structures, skin tethering, nipple discharge and axillary lymphadenopathy. In such patients, a clinical diagnosis of an inflammatory or neoplastic process is not inappropriate (2-5). Radiologic features like heterogeneous echotexture and acoustic shadows may reinforce the suspicion of a malignancy (6). The history of recent onset pain in a previously painless lump, as in our case, may be the only clue to its clinical diagnosis.
Infarction of tumors is a known albeit an uncommon complication of fine needle aspiration cytopathology. Besides tumors of the breast, it has been occasionally reported in thyroid, lymph nodes and salivary gland (1). The vascular trauma during the needling procedure may incite thrombosis and hence infarction of the tumor. Spontaneous infarction of fibroadenoma, per se a rare event, as been mostly described in the third trimester of pregnancy and lactation $(2,3,6)$. The relative ischemia for the hyperplastic tumor tissue in these physiological conditions is the most widely accepted hypothesis. Spontaneous infarction in a fibroadenoma of the breast in the absence of pregnancy or lactation is a rare enigmatic entity $(4,5,7)$. In such cases, the increased demand hypothesis is not applicable. Also, vascular lesions like thrombosis have been demonstrated only rarely. Given the rarity of spontaneous infarction, possibility of a probable torsion due to increased mobility of a fibroadenoma also remains speculative at best.

The cytopathologicalfeatures ofinfarction in a fibroadenoma are inflammation, necrosis and worrisome nuclear features of the surviving cells. Till date, all cases of spontaneous infarction of fibroadenoma have been misdiagnosed either as a high-grade malignancy or as mastitis $(4,5)$. The necrosis in a case of high-grade carcinoma is characteristically punctate and shows streaking due to smearing. Although, large chunks of necrosis may be seen, they tend to have irregular margins and non-specific shapes. The necrosis in a fibroadenoma is similar to that seen in a malignancy only in the loss of nuclei. The most striking feature is the necrotic epithelial cell clusters that maintain their typical branching staghorn shape. Although their margins may appear frayed, they are still regular and preserved. The thickness of the necrotic fragments is another important clue. The necrotic epithelial fragments appear homogenously opaque reproducing the mono-layered sheets. In contrast, the necrotic fragments in a malignancy are thick and opaque in the center and become thinner and translucent towards the edges due to the smearing effect. The necrotic stromal fragments are more difficult to distinguish from necrosis of a carcinoma and may be misinterpreted as a component of malignancy. A careful scrutiny of the necrotic fragments will invariably reveal the diagnostic necrotic epithelial clusters. A meticulous search is also likely to reveal a few preserved epithelial cell clusters, although they may scant. A diagnosis of malignancy should not be rendered in the absence of viable / unequivocal tumor cells. In cases of suspicion, a guarded report is prudent and re-aspiration or needle biopsy should be done.

In view of necrosis and the acute inflammatory response, it is also advisable to exclude the possibility of mastitis. In 
pyogenic mastitis, abundance of neutrophils is the most striking feature (8). Intra-cellular cocci are often found on diligent search. In tuberculosis, the characteristic epithelioid cells, often accompanied by multinucleate giant cells are found. The demonstration of tubercle bacilli by Ziehl Neelsen stain clinches the correct diagnosis $(8,9)$. The inspissated secretions of duct ectasia may be confused as necrosis. The typical presentation as a sub-areolar cord like mass in older women is most helpful (10).

Infarction in a fibroadenoma poses diagnostic challenge. We have presented a case of spontaneous infarction of fibroadenoma in a non pregnant adolescent girl highlighting the cytopathologic approach its correct diagnosis. This unusual complication of a common tumor should be kept in mind if necrosis is identified in the breast lump aspirate from a young female.

\section{REFERENCES}

1. Pinto RG, Couto F, Mandreker S. Infarction after fine needle aspiration. A report of four cases. Acta Cytol. 1996;40:739-41.

2. Majmudar B, Rosales-Quintana S. Infarction of breast fibroadenomas during pregnancy. JAMA. 1975;231:963-4.

3. Raju GC, Naraynsingh V. Infarction of fibroadenoma of the breast. J R Coll Surg Edinb. 1985;30:162-3.
4. Kavdia R, Kini U. WCAFTI: Worrisome cytologic alterations following tissue infarction; a mimicker of malignancy in breast cytology. Diagn Cytopathol. 2008;36:586-8.

5. Deshpande KM, Deshpande AH, Raut WK, Lele VR, Bobhate SK. Diagnostic difficulties in spontaneous infarction of a fibroadenoma in an adolescent: Case report. Diagn Cytopathol. 2002;26:26-8.

6. Sabate JM, Clotet M, Torrubia S, Gomez A, Guerrero R, de las Heras P, Lerma E. Radiologic evaluation of breast disorders related to pregnancy and lactation. Radiographics. 2007; 27 Suppl 1: S101-24.

7. Toy H, Esen HH, Sonmez FC, Kucukkartallar T. Spontaneous infarction in a fibroadenoma of the breast. Breast Care (Basel). 2011;6:54-55.

8. Nemenqani D, Yaqoob N. Fine needle aspiration cytology of inflammatory breast lesions. J Pak Med Assoc. 2009;59:167-70.

9. Fadaei-Araghi M, Geranpayeh L, Irani S, Matloob R, Kuraki S. Breast tuberculosis: Report of eight cases. Arch Iran Med. 2008; 11:463-5.

10. Javadzadeh B, Finley J, Williams HJ. Fine needle aspiration cytology of mammary duct ectasia: Report of a case with novel cytologic and immunocytochemical findings. Acta Cytol. 2001; 45:1027-31. 